\section{A major retroviral core protein related to EPA and TIMP}

WE add another curious note to the sequence similarities shared by the proteins identified by biological properties as either the erythroid-potentiating activity (EPA) factor associated with stimulation of erythroid precursors ${ }^{1}$ or the tissue inhibitor of metalloproteinases (TIMP). A recent report by Docherty et $a l^{2}$ demonstrates that these two proteins have identical sequences.

Using the Intelligenetics PEP program, we have detected regions of similarity between the EPA-TIMP protein and the gag core proteins encoded by retroviruses including human $\mathrm{T}$-cell lymphotropic virus types I, II and III (HTLV-I, -II and -III), bovine leukaemia virus (BLV), Rous sarcoma virus (RSV) and Moloney murine leukaemia virus (Mo-MuLV). These regions are congruent with those conserved among the major retroviral capsid proteins.
These gag proteins are highly divergent among themselves at both the primary and secondary structure levels as predicted by hydrophilicity profiles (Hopps and Woods algorithm $)^{3}$. Table 1 shows the alignment of the amino-acid sequences, while Fig. 1 shows that the relative position of the regions of similar sequence in the respective proteins is the same. The similarities in sequence and sequence organization may reflect either a common evolutionary origin or common function. It is noteworthy that the only region of sequence similarity between EPA and the human granulocyte-macrophage colonystimulating factor ${ }^{4}$, besides a short hydrophobic stretch close to the amino terminus, is region III, which is also the most highly conserved region among the retroviral core proteins.

The similarities reported here open the possibility that the major gag core protein may be important not only in viral assembly but also in affecting the cellular physiology so as to favour viral replication

Table 1 Alignment of amino-acid sequences in regions of similarity shown in Fig. 1

\begin{tabular}{|c|c|c|c|}
\hline Region & Origin & Position & Sequence \\
\hline I & $\begin{array}{l}\text { HTLV-III } \\
\text { HTLV-I } \\
\text { HTLV-II } \\
\text { BLV } \\
\text { Mo-MULV } \\
\text { RSV } \\
\text { EPA }\end{array}$ & $\begin{array}{l}35 \\
32 \\
32 \\
32 \\
34 \\
33 \\
-2\end{array}$ & 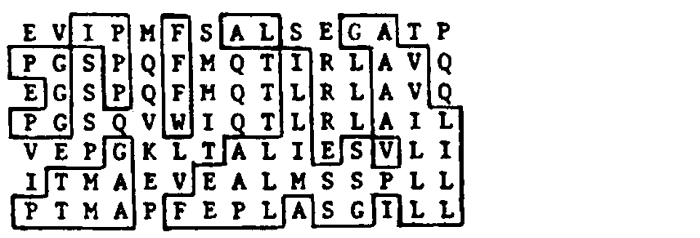 \\
\hline II & $\begin{array}{l}\text { HTLV-III } \\
\text { HTLV-I } \\
\text { HTLV-II } \\
\text { BLV } \\
\text { Mo-MuLV } \\
\text { RSV } \\
\text { EPA }\end{array}$ & $\begin{array}{l}112 \\
112 \\
112 \\
112 \\
109 \\
116 \\
75\end{array}$ & 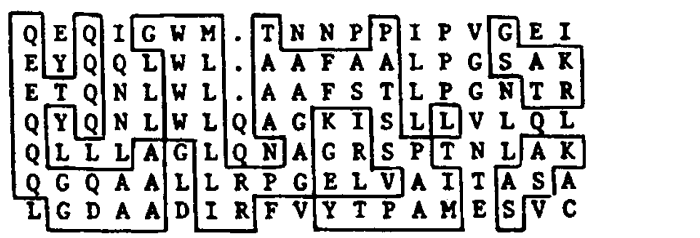 \\
\hline III & $\begin{array}{l}\text { HTLV-III } \\
\text { HTLV-I } \\
\text { HTLV-II } \\
\text { BLV } \\
\text { Mo-MuLV } \\
\text { RSV } \\
\text { EPA } \\
\text { GM-CSF }\end{array}$ & $\begin{array}{l}150 \\
133 \\
133 \\
133 \\
130 \\
149 \\
113 \\
8\end{array}$ & 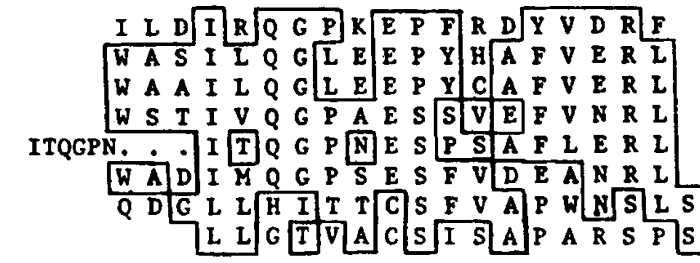 \\
\hline IV' & $\begin{array}{l}\text { HTLV-III } \\
\text { HTLV-I } \\
\text { HTLV-II }\end{array}$ & $\begin{array}{l}193 \\
185 \\
185\end{array}$ & 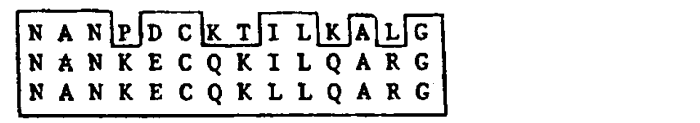 \\
\hline IV & $\begin{array}{l}\text { RSV } \\
\text { EPA }\end{array}$ & $\begin{array}{l}191 \\
153\end{array}$ & 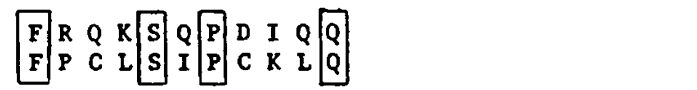 \\
\hline
\end{tabular}

Similarities among the major gag core proteins of HTLV-III ${ }^{7}, \mathrm{HTLV}-\mathrm{I}^{8}, \mathrm{HTLV}-\mathrm{II}^{9}, \mathrm{BLV}^{10}$, $M o-M u L V^{11}$ and $R_{S V} V^{12}$ and EPA ${ }^{1}$ or TIMP $P^{2}$ and the granulocyte-macrophage colony-stimulating factor $^{4}$ are shown. Common amino acids and conservative substitutions are boxed. A repeat is present in region III in Mo-MuLV.

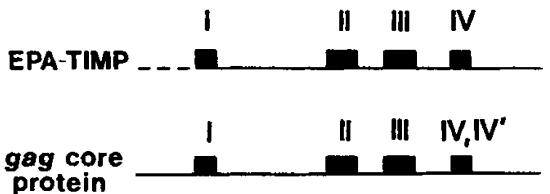

20 aa

Fig. 1 Regions of similarity between

EPA-TIMP and the major retroviral gag core proteins. aa, Amino acids.

acting as a growth factor or a protease inhibitor. In the latter case it could prevent the breakdown of proteins essential for viral replication such as reverse transcriptase or the endonuclease-integrase. These proteins are exposed to the cytoplasmic and nuclear environments during the early stages of the infection process. The major retroviral core protein may also regulate changes in the cytoskeleton during the process of budding. In this regard we note that certain pathogenic determinants of some avian and murine retroviruses have been mapped to the gag-pol region ${ }^{5,6}$. Using an analogy with the gag core protein function, EPA-TIMP may interact with RNA and with membrane proteins in its regulatory activity.

Many of the transforming oncogenes transduced by retroviruses are synthesized as fusion proteins that contain a substantial portion of the major capsid protein. The deletion of the gag determinants in some cases results in loss of transforming activity ${ }^{13}$ which could be due to loss of growth-promoting or protease inhibitory activities associated with the gag portion of the fusion product.

\section{ROBERTO PATARCA William A. HASELTINE}

Laboratory of Biochemical Pharmacology, Dana-Farber Cancer Institute, Department of Pathology, Harvard Medical School, Boston, Massachusetts 02115, USA

1. Gasson, J. C et al Nature 315, 768-771 (1985).

2. Docherty, A. J. P. et al. Nature 318, 66-69 (1985)

3. Hopps, T. P. \& Woods, K. R. Proc, natn. Acad. Sci U.S.A. 78,3824 (1981).

4. Lee, F. et al. Proc. natn. Acad. Sci U.S.A. 82, 4360-4364 (1985).

5. Robinson, H. L., Blais, B. M., Tsichlis, P. W. \& Coffin, J. M. Proc. natn. Acad. Sci. U.S.A. 79, 1225-1229 (1982).

6. Holland, C. A., Hartley, J. W., Rowe, W. P. \& Hopkins, N. J. J. Virol. 53, 158-165 (1985)

7. Ratner, L. et al. Nature 313, 277-284 (1985)

8. Seiki, M. et al Proc. natn. Acad Sci. U.S.A. 80, 3618-3622 (1983).

9. Shimotohno, K. et al. Proc. natn. Acad. Sci. U.S.A. 82, 3101-3105 (1985).

10. Sagata, N. et al. Proc. natn. Acad. Sci. U.S.A. 82, 677-681 (1985).

11. Shinnick, T. M., Lerner, R. A. \& Sutcliffe, A. Nature 293, 543-548 (1981).

2. Shwarts, E., Tizard, R. \& Gilbert, W. Cell 32, 853-869 (1983).

13. Prywes, R. et al. Cell 34, 569-579 (1983) 